\title{
Optimization of cardamom fruit ethanol extract gel with combination of HPMC and Sodium Alginate as the gelling agent using Simplex Lattice Design
}

\section{Optimasi formula gel ekstrak etanol buah kapulaga dengan kombinasi gelling agent HPMC dan Natrium Alginat menggunakan simplex lattice design}

\author{
Wati Eliana Putri ${ }^{1}$, Metha Anung Anindhita ${ }^{*}$ \\ ${ }^{1}$ Program Studi S-1 Farmasi, Fakultas Farmasi, Universitas Pekalongan, Pekalongan, Indonesia \\ *Corresponding author e-mail: anindhita.m.a@gmail.com
}

\begin{abstract}
Background: Cardamom has been studied and proven to be effective as an antibacterial. Gel preparations are preferred because they have advantages such as being easy to apply, providing a cooling effect and being able to deliver drugs well.

Objective: The purpose of this study was to make a gel formulation of ethanolic cardamom fruit extract by optimizing the combination of gelling agent of HPMC and sodium alginate using the simplex lattice design (SLD).

Methods: Cardamom fruit extract was obtained by extracting cardamom fruit simplicia using $70 \%$ ethanol. The formulation of the gel preparation from cardamom fruit extract was optimized using the SLD method on Design Expert. There were 5 gel formulas made and evaluated including organoleptic, $\mathrm{pH}$, viscosity, spreadability, and adhesion. The independent variables in SLD were the amount of HMC and sodium alginate, while the responses included viscosity, spreadability, and adhesion. Optimal formula selection is done by using a numerical approach.

Results: FI (HPMC $3.75 \%$ and sodium alginate $2.75 \%$ ) and FII (HPMC $3.50 \%$ and sodium alginate $3.00 \%)$ met the test criteria for all the tests performed. The optimal formula suggested by SLD is a combination of $3.53 \%$ HPMC and $2.98 \%$ sodium alginate with a desirability value of 1.00 . The predicted value for each response were viscosity of $214.83 \mathrm{dPa}$.s, dispersion of $5.38 \mathrm{~cm}$, and adhesion of 50.08 seconds. The optimal formula showed a dispersion value of $5.37 \mathrm{~cm}$. The results of the t-test indicated that the dispersion value of the observed results is not significantly different from the prediction software.

Conclusion: Based on this research, it can be concluded that the use of a combination of HPMC and sodium alginate as a gelling agent can be optimized by using simplex lattice design to obtain the optimum formula for cardamom fruit extract gel.
\end{abstract}

Keywords: gel, hpmc, sodium alginate, SLD, kapulaga

\section{Intisari}

Latar Belakang: Kapulaga telah diteliti dan terbukti dapat dimanfaatkan sebagai antibakteri. Sediaan gel disukai karena memiliki keunggulan antara lain mudah merata bila dioleskan, memberikan efek dingin serta dapat menghantarkan obat dengan baik.

Tujuan: Penelitian ini bertujuan untuk membuat formulasi sediaan gel ekstrak buah kapulaga dengan mengoptimasi penggunaan kombinasi gelling agent HPMC dan natrium alginat menggunakan metode Simplex Lattice Design (SLD).

Metode: Ekstrak buah kapulaga diperoleh dengan mengekstraksi simplisia buah kapulaga menggunakan etanol 70\%. Formulasi sediaan gel dari ekstrak buah kapulaga dioptimasi menggunakan metode $S L D$ pada Design Expert. Terdapat 5 formula gel yang dibuat dan dievaluasi meliputi organoleptis, pH, viskositas, daya sebar, dan daya lekat. Variabel bebas pada SLD adalah jumlah HMC dan natrium alginat, sedangkan responnya meliputi viskositas, daya sebar, dan daya lekat. Pemilihan formula optimum dilakukan menggunakan pendekatan numerical.

Hasil: FI (HPMC 3,75\% dan natrium alginat 2,75\%) dan FII (HPMC 3,50\% dan natrium alginat 3,00\%) memenuhi kriteria uji semua pengujian yang dilakukan. Formula optimal yang disarankan SLD adalah kombinasi HPMC 3,53\% dan natrium alginat 2,98\% memiliki desirability 1,00 dengan prediksi viskositas bernilai $214,83 \mathrm{dPa} . \mathrm{s}$, daya sebar bernilai $5,38 \mathrm{~cm}$, dan daya lekat 50,08 detik. Pengujian 
108 | Putri, W. E., dkk /Jurnal Ilmiah Farmasi (Scientific Journal of Pharmacy) Special Edition 2022, $107-120$

terhadap formula optimal hasil optimasi $S L D$ menunjukkan nilai daya sebar $5,37 \mathrm{~cm}$ sesuai dengan nilai respon pada $S L D$. Hasil uji-t menunjukkan nilai daya sebar hasil observasi tidak berbeda signifikan dibandingkan dengan prediksi software.

Kesimpulan: Berdasarkan penelitian ini dapat disimpulkan bahwa penggunaan variasi HPMC dan natrium alginat sebagai gelling agent dalam formula gel ekstrak buah kapulaga dapat dioptimasi menggunakan simplex lattice design.

Kata kunci : gel, hpmc, natrium alginat, $S L D$, kapulaga

\section{Pendahuluan}

Bangsa Indonesia turun temurun menggunakan tanaman sebagai obat untuk pengobatan dan pencegahan beberapa penyakit. Masyarakat lebih banyak menggunakan obat tradisional karena dinilai lebih aman dan memiliki efek samping kecil (Sumayyah \& Salsabila, 2017). Salah satu tanaman yang berkhasiat obat adalah kapulaga, memiliki banyak khasiat salah satunya adalah antibakteri. Kapulaga mengandung senyawa metabolit sekunder fenol, tanin, terpenoid yang mampu menghambat bakeri Escherichia coli dan Staphylococcus aureus (Sukandar et al., 2016)

Sediaan dalam bentuk gel banyak dipilih karena memiiki banyak keunggulan, karena dapat menghasilkan penyebaran pada kulit yang baik, pelepasan obat baik, memiliki tampilan sediaan jernih dan elegan, bila diaplikasikan akan meninggalkan film tembus pandang, mudah dicuci dan stabil pada penyimpanan (Yulia et al., 2021). Pada sediaan gel, gelling agent adalah bahan yang berperan dalam membentuk basis gel.

HPMC adalah salah satu gelling agent yang merupakan derivat selulosa, memiliki viskositas yang stabil pada penyimpanan jangka panjang, namun juga memiliki kekurangan, penelitian sebelumnya oleh Fulviana (2013) dikatakan bahwa kenaikan HPMC akan menurunkan daya sebar dari sediaan gel, penurunan daya sebar sediaan gel ini merugikan untuk sediaan karena berarti kemampuan zat aktif untuk menyebar dan kontak dengan kulit semakin kecil, kriteria daya sebar sediaan gel yang baik menurut standar SNI-06-2588 adalah 5-7 cm. Konsentrasi HPMC yang digunakan sebagai acuan untuk membuat formula sama seperti pada penelitian sebelumnya oleh Fulviana (2013) berkisar 4-8\%. Natrium alginat dihasilkan dari ganggang coklat dengan kandungan bahan lendir hingga 40\%, gel dengan kandungan natrium alginat menunjukkan penyebaran yang sangat baik, selain itu natrium alginat memiliki sifat pelicin, tidak lengket, tidak terasa saat digunakan dan menunjukkan sifat emolien (Agoes, 2012). Konsentrasi natrium alginat sebagai gelling agent berkisar 2-6\%.

Metode simplex lattice design (SLD), salah satu metode desain eksperimental, merupakan metode yang efektif, sederhana dan cepat dalam penggunaannya untuk membuat formula sediaan dibandingkan metode trial and error. Metode ini memberikan 
109 Putri, W. E., dkk /Jurnal Ilmiah Farmasi (Scientific Journal of Pharmacy) Special Edition 2022, $107-120$

perbandingan penggunaan gelling agent yang mengacu pada konsentrasi bahan yang digunakan sebagai gelling agent, kemudian dapat mengetahui profil efek campuran kombinasi gelling agent terhadap suatu parameter yakni sifat fisik gel yang dibuat (Bolton, 1997). Parameter sifat fisik yang bisa diuji seperti viskositas, daya sebar dan daya lekat, karena ketiganya menghasilkan data yang berupa nilai.

Berdasarkan latar belakang tersebut, peneliti tertarik karena terdapat kemungkinan penggunaan kombinasi HPMC dan natrium alginat dapat memberikan sifat fisik sediaan gel ekstrak etanol buah kapulaga yang memenuhi kriteria uji dan diperoleh formula optimal sediaan gel menggunakan metode SLD.

\section{Metode}

\subsection{Bahan}

Buah kapulaga, etanol 70\%, $\mathrm{FeCl}_{3}$ (Merck), $\mathrm{HCl}$ (Merck), $\mathrm{H}_{2} \mathrm{SO}_{4}$ (Merck), asam galat (Merck), asam tanin (Merck), terpineol, HPMC SH 90 (Bate Chemical Co.Ltd.), metil paraben (Bate Chemical Co.Ltd.), propil paraben (Bate Chemical Co.Ltd.), akuades.

\subsection{Jalannya penelitian}

\subsubsection{Pembuatan simplisia}

Pembuatan simplisia dilakukan dengan mencuci bersih buah kapulaga basah terlebih dahulu untuk menghilangkan kotoran tanah dan cemaran pestisida yang menempel, sortasi basah dengan memisahkan kapulaga busuk, dijemur dibawah sinar matahari dengan ditutupi kain hitam agar proses penjemuran bisa berlangsung cepat namun kandungan senyawa tidak rusak karena terlalu panas, dijemur hingga kering yang ditandai dengan penimbangan konstan, selanjutnya dilakukan disortasi kering untuk memisahkan kapulaga yang mengalami pembusukan, kemudian dihaluskan dengan alat hingga menjadi serbuk.

\subsubsection{Ekstraksi}

Ekstraksi dilakukan dengan menggunakan pelarut etanol 70\%. Proses ekstraksi dilakukan dengan memasukkan simplisia ke dalam toples kaca, ditambahkan pelarut hingga perbandingan bagian serbuk: pelarut adalah 1:3, proses maserasi selama 3 x 24 jam dengan sering dilakukan pengadukan, selanjutnya rendaman tadi disaring untuk memisahkan ampas dari filtrat. Selanjutnya filtrat ekstrak dievaporasi menggunakan vacuum rotary evaporator pada suhu $60^{\circ} \mathrm{C}$ dengan kecepatan putaran $50 \mathrm{rpm}$ hingga sedikit mengental dan dipindahkan ke cawan porselin untuk dilanjutkan pengentalan dengan waterbath pada suhu $60^{\circ} \mathrm{C}$ hingga didapat ekstrak kental.

\subsubsection{Rendemen ekstrak}


110 | Putri, W. E., dkk /Jurnal Ilmiah Farmasi (Scientific Journal of Pharmacy) Special Edition 2022, $107-120$

Perhitungan rendemen dilakukan dengan membandingkan jumlah ekstrak etanol buah kapulaga yang didapat dengan bobot simplisia awal dan mengalikannya dengan 100\%, sehingga didapat presentase rendemen ekstrak.

$$
\% \text { Rendemen }=\frac{\text { Bobot ekstrak }}{\text { Bobot simplisia }} \times 100 \%
$$

\subsubsection{Uji kandungan senyawa metabolit sekunder}

\subsubsection{Uji fenol}

Ekstrak etanol buah kapulaga sebanyak 1,5 gram dilarutkan dengan etanol 70\% sebanyak $15 \mathrm{~mL}$ dan disaring menggunakan kertas saring, filtrat dipipet sebanyak $5 \mathrm{~mL}$ ke dalam tabung reaksi, kemudian tambahkan larutan $\mathrm{FeCl}_{3}$ 1\%, diamati warna larutannya. Apabila berwarna hitam kebiruan atau hijau kehitaman artinya sampel mengandung senyawa fenol. Pada pengujian ini digunakan asam galat sebagai pembanding.

\subsubsection{Uji tanin}

Ekstrak etanol buah kapulaga sebanyak 1,5 gram dilarutkan dengan etanol 70\% sebanyak $15 \mathrm{~mL}$ dan disaring menggunakan kertas saring, filtrat dipipet sebanyak $2 \mathrm{~mL}$ ke dalam tabung reaksi, dilakukan pemanasan selama 5 menit, kemudian ditambahkan dengan 2-3 tetes larutan $\mathrm{FeCl}_{3}$ 1\%, dan diamati perubahan warna larutan. Apabila berwarna hitam kebiruan atau hijau kehitaman artinya sampel mengandung senyawa tanin. Pada pengujian ini digunakan pembanding berupa asam tanin.

\subsubsection{Uji terpenoid}

Ekstrak etanol buah kapulaga dilarutkan dengan pelarutnya dan disaring, filtrat dipipet sebanyak $5 \mathrm{~mL}$ ke dalam tabung reaksi, ditambahkan dengan $2 \mathrm{~mL} \mathrm{HCl}$, dilakukan penggojokan, kemudian ditambahkan $\mathrm{H}_{2} \mathrm{SO}_{4}$ sebanyak 2-3 tetes, dilakukan pengamatan warna larutan apabila muncul warna coklat kemerahan atau coklat kehijauan artinya sampel tersebut mengandung senyawa terpenoid. Senyawa terpineol digunakan sebagai pembanding pada pengujian ini.

\subsubsection{Pembuatan sediaan}

Sediaan gel dibuat sesuai desain pada Tabel 1 dengan memasukkan akuades panas pada mortir, dikembangkan HPMC dan natrium alginat secara terpisah, setelah membentuk fasa gel dicampurkan pada satu mortir, ditambahkan metil paraben dan propil paraben yang telah dilarutkan terlebih dahulu dengan sedikit etanol, ditambahkan ekstrak etanol buah kapulaga yang telah dilarutkan terlebih dahulu dengan akuades, selanjutnya disaring dan dicampurkan semua komponen hingga homogen. Sediaan dibuat sejumah 30 gram untuk tiap formula. 
111 | Putri, W. E., dkk /Jurnal Ilmiah Farmasi (Scientific Journal of Pharmacy) Special Edition 2022, $107-120$

Tabel 1. Desain formula gel ekstrak etanol 70\% buah kapulaga

\begin{tabular}{|c|c|c|c|c|c|c|}
\hline \multirow[t]{2}{*}{$\begin{array}{c}\text { Kode } \\
\text { formulasi }\end{array}$} & \multicolumn{2}{|c|}{$\begin{array}{c}\text { Proporsi } \\
\text { (\%) }\end{array}$} & \multicolumn{2}{|c|}{$\begin{array}{c}\text { Proporsi } \\
\text { jumlah (mg) }\end{array}$} & \multirow[t]{2}{*}{$\begin{array}{c}\text { Jumlah Metil } \\
\text { paraben (g) }\end{array}$} & \multirow[t]{2}{*}{$\begin{array}{c}\text { Jumlah Propi } \\
\text { paraben (g) }\end{array}$} \\
\hline & $\mathrm{X} 1$ & $\mathrm{X} 2$ & X1 & $\mathrm{X} 2$ & & \\
\hline F1 & 3,75 & 2,75 & 1,125 & 0,825 & 0,06 & 0,06 \\
\hline $\mathrm{F} 2$ & 3,50 & 3,00 & 1,050 & 0,900 & 0,06 & 0,06 \\
\hline F3 & 4,00 & 2,50 & 1,200 & 0,750 & 0,06 & 0,06 \\
\hline F4 & 4,25 & 2,25 & 1,275 & 0,675 & 0,06 & 0,06 \\
\hline F5 & 4,50 & 2,00 & 1,350 & 0,600 & 0,06 & 0,06 \\
\hline $\begin{array}{l}\text { Keterangan } \\
\mathrm{X} 1=\text { HPMC } \\
\mathrm{X} 2 \text { = Natriur }\end{array}$ & jinat & & & & & \\
\hline
\end{tabular}

\subsubsection{Uji sifat fisik}

\subsubsection{Uji organoleptis}

Pengujian organoleptis dilakukan dengan mengamati langsung secara visual bentuk, warna dan bau dari sediaan gel. Karakteristik sediaan gel yang diharapkan adalah berbentuk semi padat dan warna yang jernih. Kriteria uji organoleptis dari sediaan gel yang baik adalah warna, bau dan bentuk memenuhi spesifikasi bahan yang digunakan dan dapat diterima (Ansel, 1989).

\subsubsection{Uji homogenitas}

Pengujian homogenitas dilakukan dengan mengambil sebanyak 0,5 gram sediaan gel dan meletakkannya pada cawan petri, kemudian ditutup dengan tutup cawan petri. Sediaan gel seharusnya homogen yang ditunjukkan dengan tidak adanya butiran serbuk bahan (Lachman et al., 1994).

\subsubsection{Uji $p H$}

Pengujian pH dilakukan dengan menimbang 0,5 gram sediaan gel, kemudian dilarutkan dalam $50 \mathrm{~mL}$ akuades, dilakukan pengukuran menggunakan $\mathrm{pH}$ meter, hasil yang ditunjukkan oleh $\mathrm{pH}$ meter tersebut dicatat. Sediaan gel yang digunakan untuk diaplikasikan pada kulit seharusnya memiliki pH antara 4,5 sampai 6,5 (Naibaho et al., 2013).

\subsubsection{Uji viskositas}

Pengujian viskositas dilakukan dengan memasukkan sediaan gel pada beaker glass dan memasang rotor pada alat uji, dikondisikan agar rotor tercelup sediaan gel, diamati skala yang ditunjuk jarum hingga menunjukkan angka yang stabil, nilai viskositas yang baik adalah sebesar 200 sampai $400 \mathrm{dPa} \cdot \mathrm{s}$ (Septiani et al., 2012).

\subsubsection{Uji daya sebar}

Penentuan daya sebar dilakukan dengan menimbang sebanyak 0,5 gram sediaan gel dan meletakkannya di atas cawan petri, ditutup dengan tutup cawan petri, dengan jangka 
112 | Putri, W. E., dkk /Jurnal Ilmiah Farmasi (Scientific Journal of Pharmacy) Special Edition 2022, $107-120$

sorong diukur diameter gel, selanjutnya ditambahkan beban tambahan dengan anak timbangan 50, 100, 150, dan 200 gram. Setiap penambahan beban didiamkan dahulu selama 1 menit, kemudian diukur kembali diameter gel (Yuniarto et al., 2012). Kriteria daya sebar sediaan gel yang baik adalah 5-7 cm (Voigt, 1994).

\subsubsection{Uji daya lekat}

Penentuan daya lekat dilakukan dengan menimbang sebanyak 0,5 gram sediaan gel, meletakkannya di atas gelas objek yang menempel pada lemari kaca dan dikaitkan dengan tali, kemudian ditutup dengan gelas objek lain, memberikan beban diatasnya sebesar $1 \mathrm{~kg}$ selama 5 menit, setelah selesai diambil beban tersebut dan pada tali dikaitkan beban sebesar 80 gram bersamaan dengan dinyalakan stopwatch, dicatat waktu yang diperlukan untuk kedua gelas objek tersebut lepas. Kriteria daya lekat sediaan gel yang baik adalah lebih dari 10 detik (Voigt, 1994).

\subsection{Analisis hasil}

Data hasil pengujian dianalisis menggunakan software Design Expert versi 13 menggunakan metode simplex lattice design. Dihasilkan 5 formula dari simplex lattice design dengan analisis data yang dilakukan yaitu viskositas, daya sebar dan daya lekat. Pengaruh variabel bebas terhadap respon dianalisis menggunakan ANOVA yang ada pada simplex lattice design. Optimasi dilakukan dengan pendekatan numeric sehingga didapatkan hasil formula optimal dan prediksi respon.

\section{Hasil dan pembahasan}

\subsection{Hasil ekstraksi}

Sebanyak 1,139 gram simplisia kapulaga yang diekstraksi, menghasilkan rendemen ekstrak 39,21 gram (3,44\% b/b). Nilai rendemen dapat menunjukkan keefektifan dari proses ekstraksi yang dipengaruhi oleh penyari, ukuran simplisia, metode serta lamanya ekstraksi berlangsung. Ekstrak yang dihasilkan memiliki kadar air sebesar 9,49\% sehingga memenuhi syarat kadar air dalam ekstrak yaitu kurang dari 10\%. Kandungan air yang besar pada ekstrak dapat menyebabkan ekstrak mudah ditumbuhi oleh mikroorganisme.

\subsection{Identifikasi metabolit sekunder}

Identifikasi metabolit sekunder senyawa pada ekstrak tersaji pada Tabel 2. Pada pengujian kandungan fenol, diamati warna larutan hijau kehitaman yang artinya sampel positif mengandung senyawa fenol. Perubahan warna ini terjadi karena adanya reaksi antara senyawa fenol dengan ion $\mathrm{Fe}^{3+}$ yang membentuk suatu senyawa kompleks. Pada pengujian kandungan tanin, adanya warna larutan hijau kehitaman mengindikasikan 
113 | Putri, W. E., dkk /Jurnal Ilmiah Farmasi (Scientific Journal of Pharmacy) Special Edition 2022, $107-120$

bahwa ekstrak mengandung tanin. Hal ini terjadi karena senyawa tanin akan membentuk senyawa kompleks dengan ion $\mathrm{Fe}^{3+}$.

Pada uji terpenoid diketahui warna larutan menjadi coklat kemerahan yang artinya ekstrak mengandung senyawa terpenoid. Hal ini terjadi karena kemampuan senyawa terpenoid yang akan membentuk warna dengan adanya asam $\mathrm{H}_{2} \mathrm{SO}_{4}$ pekat dalam pelarut asam klorida.

Tabel 2. Hasil identifikasi senyawa pada ekstrak

\begin{tabular}{lllc}
\hline \multicolumn{1}{c}{ Pengujian } & \multicolumn{2}{c}{ Warna larutan } & Hasil \\
\cline { 2 - 3 } & \multicolumn{1}{c}{ Baku pembanding } & \multicolumn{1}{c}{ Larutan uji } & \\
\hline Uji fenol & Hijau kehitaman & Hijau kehitaman & + \\
Uji tanin & Hijau kehitaman & Hijau kehitaman & + \\
Uji terpenoid & Coklat kemerahan & Coklat kemerahan & $\mathbf{+}$ \\
\hline Keterangan & & & \\
$+=$ menandakan ekstrak mengandung senyawa yang diuji &
\end{tabular}

\subsection{Sifat fisik formula}

Evaluasi sifat fisik sediaan gel ekstrak etanol buah kapulaga dapat dilihat pada Tabel 3.

Tabel 3. Hasil uji sifat fisik

\begin{tabular}{|c|c|c|c|c|c|}
\hline \multirow{2}{*}{ Uji sifat fisik } & \multicolumn{5}{|c|}{ Formula } \\
\hline & F1 & $\mathrm{F} 2$ & F3 & $\mathrm{F} 4$ & F5 \\
\hline Organoleptis & $\begin{array}{l}\text { Semi padat, } \\
\text { kuning }\end{array}$ & $\begin{array}{l}\text { Semi padat, } \\
\text { kuning }\end{array}$ & $\begin{array}{l}\text { Semi padat, } \\
\text { kuning }\end{array}$ & $\begin{array}{l}\text { Semi padat, } \\
\text { kuning }\end{array}$ & $\begin{array}{l}\text { Semi padat, } \\
\text { kuning }\end{array}$ \\
\hline & $\begin{array}{c}\text { kecoklatan, } \\
\text { aroma khas } \\
\text { ekstrak } \\
\text { kapulaga }\end{array}$ & $\begin{array}{c}\text { kecoklatan, } \\
\text { aroma khas } \\
\text { ekstrak } \\
\text { kapulaga }\end{array}$ & $\begin{array}{c}\text { kecoklatan, } \\
\text { aroma khas } \\
\text { ekstrak } \\
\text { kapulaga }\end{array}$ & $\begin{array}{c}\text { kecoklatan, } \\
\text { aroma khas } \\
\text { ekstrak } \\
\text { kapulaga }\end{array}$ & $\begin{array}{c}\text { kecoklatan, } \\
\text { aroma khas } \\
\text { ekstrak } \\
\text { kapulaga }\end{array}$ \\
\hline Homogenitas & Homogen & Homogen & Homogen & Homogen & Homogen \\
\hline $\mathrm{pH}$ & $6,16 \pm 0,11$ & $6,46 \pm 0,05$ & $6,10 \pm 0,00$ & $6,03 \pm 0,05$ & $6,00 \pm 0,00$ \\
\hline Viskositas $(\mathrm{dPa} \cdot \mathrm{s})$ & $266 \pm 14,43$ & $206 \pm 5,77$ & $282 \pm 2,88$ & $286 \pm 12,58$ & $306 \pm 5,77$ \\
\hline Daya sebar $(\mathrm{cm})$ & $5,20 \pm 0,08$ & $5,35 \pm 0,00$ & $4,96 \pm 0,02$ & $4,63 \pm 0,02$ & $4,37 \pm 0,12$ \\
\hline Daya lekat (detik) & $53,00 \pm 0,30$ & $50,00 \pm 1,06$ & $57,49 \pm 0,23$ & $61,40 \pm 0,24$ & $65,00 \pm 0,45$ \\
\hline
\end{tabular}

Hasil uji organoleptis terhadap F1, F2, F3, F4 dan F5 menunjukkan bahwa formula tersebut memiliki sifat organoleptis yang sama yaitu bentuk sediaan semi padat, warna kuning kecoklatan dan bau khas ekstrak kapulaga (Tabel 3). Sifat organoleptis sediaan gel dihasilkan dari kombinasi bahan yang digunakan yaitu HPMC, natrium alginat, metil paraben dan propil paraben yang berbentuk serbuk sedangkan akuades berbentuk cair sehingga dengan komposisi yang tepat dapat diperoleh sediaan semi padat dengan konsistensi tertentu. Warna sediaan dihasilkan dari ekstrak kapulaga karena bahan lain berwarna putih dan tidak berwarna. Bau sediaan dihasilkan dari ekstrak kapulaga yang memiliki bau khas dan kuat sedangkan bahan lain tidak berbau.

Hasil uji homogenitas F1, F2, F3, F4 dan F5 menunjukkan semua sediaan bersifat homogen tidak ada partikel serbuk bahan (Tabel 3). Hal ini menggambarkan bahwa ekstrak dan bahan tambahan terlarut dan tercampur dengan baik sehingga memenuhi kriteria 
114 | Putri, W. E., dkk /Jurnal Ilmiah Farmasi (Scientific Journal of Pharmacy) Special Edition 2022, $107-120$

homogenitas sediaan. Sediaan yang homogen menjamin jumlah zat aktif yang seragam pada setiap pengambilan.

Berdasarkan pengujian $\mathrm{pH}$ yang dilakukan seperti tersaji pada Tabel 3 diketahui bahwa nilai $\mathrm{pH}$ dari kelima formula memenuhi kriteria $\mathrm{pH}$ sediaan topikal yaitu masuk dalam rentang pH 4,5-6,5 (Draelos \& Thaman, 2006). Sediaan topikal dengan pH terlalu rendah dapat mengiritasi kulit, sedangkan apabila terlalu basa maka dapat menyebabkan kulit menjadi kering. Perbedaan nilai $\mathrm{pH}$ dari kelima formula disebabkan karena perbedaan penggunaan komposisi gelling agent tiap formula, HPMC memiliki rentang nilai pH 3-11 dan natrium alginat sebesar 5-10.

Hasil uji viskositas seperti yang tertera pada Tabel 3 menunjukkan bahwa viskositas dari kelima formula memenuhi kriteria viskositas yang dapat diterima yaitu dalam rentang 200-400 dPa·s (Septiani et al., 2012). Viskositas sediaan menggambarkan kekentalan sediaan yang dihasilkan. Nilai viskositas yang berbeda pada tiap formula disebabkan karena perbedaan komposisi gelling agent. Penggunaan HPMC yang lebih banyak akan menghasilkan sediaan dengan viskositas lebih tinggi, sedangkan penggunaan natrium alginat yang lebih banyak akan menurunkan viskositas yang dihasilkan karena karakteristik natrium alginat yang licin sehingga menghasilkan sediaan yang lembut.

Hasil uji daya sebar seperti tersaji pada Tabel 3 menunjukkan hanya F1 dan F2 yang memenuhi kriteria yaitu berada dalam rentang 5-7 cm (Voigt, 1994). Daya sebar sediaan menggambarkan kemampuan penyebaran pada kulit. Daya sebar baik menjamin pemerataan saat diaplikasikan yang mana berpengaruh pada absorbsi obat, daya sebar yang rendah berarti kontak dengan kulit kecil sehingga daya hambat aktibakteri tidak akan optimal. Perbedaan daya sebar tiap formula disebabkan karena perbedaan komposisi penggunaan gelling agent. Penggunaan HPMC yang lebih banyak menghasilkan sediaan dengn daya sebar lebih kecil dan penggunaan natrium alginat lebih banyak akan menghasilkan daya sebar lebih tinggi, hal ini karena natrium alginat yang memiliki kandungan bahan lendir $40 \%$ sehingga bersifat licin dan mudah menyebar.

Hasil uji daya lekat seperti tersaji pada Tabel 3 menunjukkan daya lekat yang dimiliki oleh kelima formula memenuhi kriteria karena sediaan dapat melekat lebih dari 10 detik (Suyudi, 2014). Daya lekat sediaan menggambarkan kemampuan melekat pada kulit, daya lekat tinggi menandakan sediaan tidak mudah hilang. Perbedaan daya lekat pada tiap formula disebabkan karena perbedaan komposisi penggunaan gelling agent. Penggunaan HPMC lebih banyak akan menghasilkan daya lekat lebih besar, sedangkan natrium alginat yang lebih banyak akan menurunkan daya lekat. Hal ini terjadi karena HPMC memiliki 
115 | Putri, W. E., dkk /Jurnal Ilmiah Farmasi (Scientific Journal of Pharmacy) Special Edition 2022, $107-120$

ikatan lebih kuat sehingga dapat melekat lebih lama, sedangkan penggunaan natrium alginat lebih banyak akan menjadikan sediaan lebih licin sehingga daya lekat lebih kecil.

\subsection{Optimasi formula dengan simplex lattice design}

Pada penentuan formula optimum dengan metode simplex lattice design, parameter uji yang digunakan meliputi viskositas, daya sebar dan daya lekat gel. Data hasil pengujian ketiga parameter tersebut dimasukkan ke dalam software untuk menentukan pengaruh kombinasi bahan terhadap respon.

\subsubsection{Viskositas}

Respon viskositas dari hasil pengujian dimasukkan ke dalam software. Selanjutnya dilakukan analisis hasil ANOVA sehingga diperoleh hasil seperti tertera pada Tabel 4.

Tabel 4. Hasil uji ANOVA viskositas

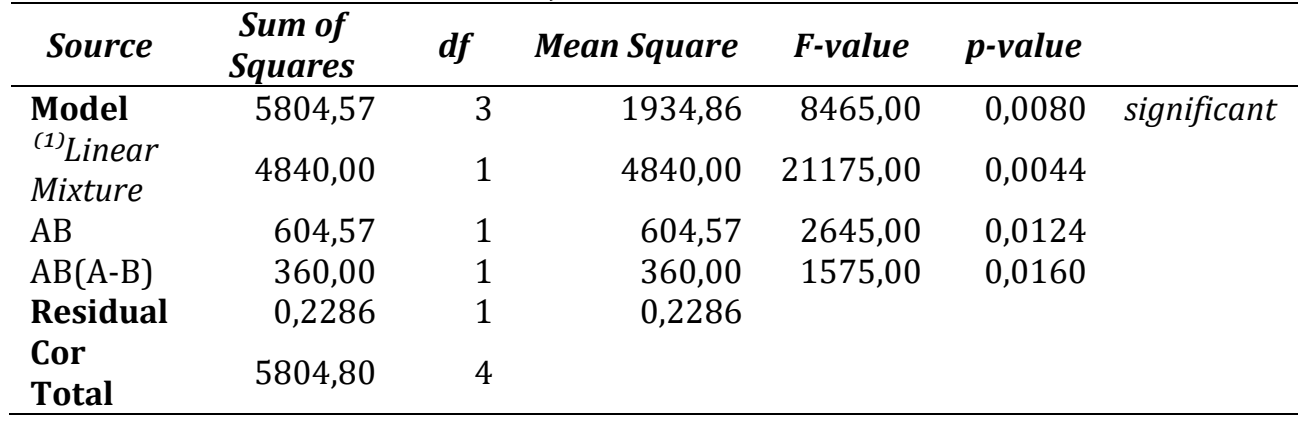

Model tersebut memiliki nilai probabilitas model dengan $p$-value $<0,0160$ artinya signifikan dimana peluang yang didapatkan di luar toleransi peneliti $<0,05$. Berdasarkan nilai tersebut hanya 0,80\% kemungkinan terjadi noise. Nilai lack of fit (F-value) sebesar 1575,00 yang menunjukkan tidak signifikan, nilai $F$-value yang tidak signifikan adalah syarat untuk model yang baik karena menandakan adanya kesesuaian data dengan respon. Profil kurva dari model prediksi respon viskositas tersaji pada Gambar 1.

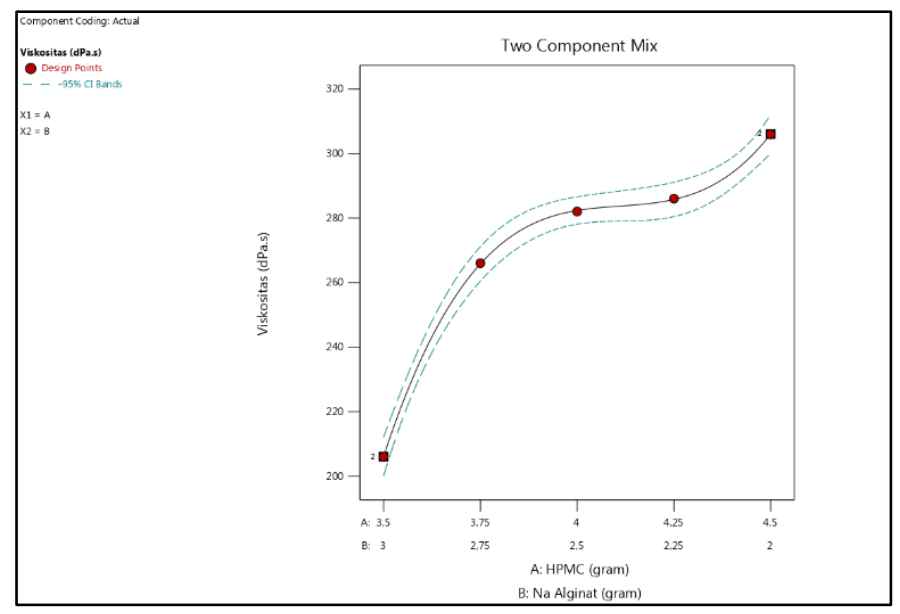

Gambar 1. Grafik hubungan kombinasi gelling agent dengan viskositas gel 
116 | Putri, W. E., dkk /Jurnal Ilmiah Farmasi (Scientific Journal of Pharmacy) Special Edition 2022, $107-120$

Grafik pada Gambar 1 memperlihatkan bahwa semakin tinggi konsentrasi HPMC yang digunakan maka viskositas sediaan semakin tinggi. Nilai viskositas akan menurun seiring kenaikan konsentrasi dari natrium alginat.

\subsubsection{Uji daya sebar}

Respon daya sebar dari hasil pengujian dimasukkan ke dalam software. Selanjutnya dilakukan analisis hasil ANOVA sehingga diperoleh hasil seperti tertera pada Tabel 5.

Tabel 5. Hasil uji ANOVA daya sebar

\begin{tabular}{lrrrrrr}
\hline \multicolumn{1}{c}{ Source } & $\begin{array}{c}\text { Sum of } \\
\text { Squares }\end{array}$ & \multicolumn{1}{c}{$\boldsymbol{d} \boldsymbol{f}$} & Mean Square & F-value & \multicolumn{1}{c}{$\boldsymbol{p}$-value } & \\
\hline Model & 0,6350 & 1 & 0,6350 & 199,70 & 0,0008 & significant \\
${ }^{(1)}$ Linear & 0,6350 & 1 & 0,6350 & 199,70 & 0,0008 & \\
Mixture & & 3 & 0,0032 & & & \\
Residual & 0,0095 & & & & & \\
Cor Total & 0,6446 & 4 & & & &
\end{tabular}

Model tersebut memiliki nilai probabilitas model dengan p-value sebesar 0,0008 artinya signifikan dimana peluang yang didapatkan di luar toleransi peneliti <0,05. Berdasarkan nilai tersebut hanya 0,08\% kemungkinan terjadi noise. Nilai lack of fit (F-value) sebesar 199,70 yang menunjukkan tidak signifikan, nilai $F$-value yang tidak signifikan adalah syarat untuk model yang baik karena menandakan adanya kesesuaian data dengan respon. Profil kurva dari model prediksi respon daya sebar tersaji pada Gambar 2.

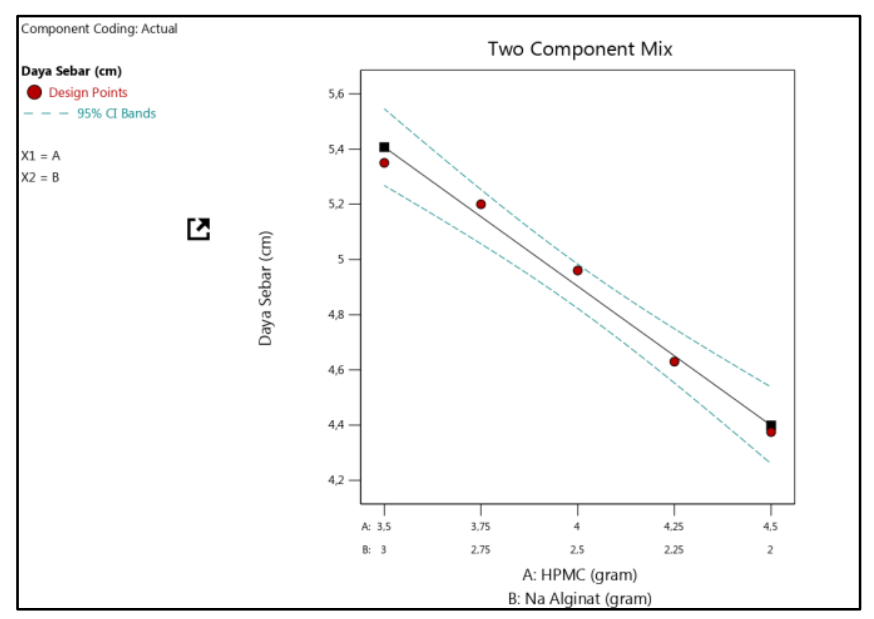

Gambar 2. Grafik hubungan kombinasi gelling agent dengan daya sebar gel

Grafik pada Gambar 2 memperlihatkan bahwa semakin tinggi konsentrasi natrium alginat yang digunakan daya sebar yang didapat semakin tinggi, sedangkan semakin tinggi konsentrasi HPMC yang digunakan menurunkan daya sebar sediaan. Penggunaan HPMC akan memberikan konsistensi yang kental sehingga konsistensi sediaan tinggi akibatnya daya sebarnya kecil. Penambahan natrium alginat membantu memperbaiki daya sebar karena natrium alginat memiliki kandungan bahan lendir sebanyak $40 \%$ sehingga bersifat licin dan mempermudah penyebarannya. 
117 | Putri, W. E., dkk /Jurnal Ilmiah Farmasi (Scientific Journal of Pharmacy) Special Edition 2022, $107-120$

\subsubsection{Uji daya lekat}

Respon daya lekat dari hasil pengujian dimasukkan ke dalam software. Selanjutnya dilakukan analisis hasil ANOVA sehingga diperoleh hasil seperti tertera pada Tabel 6.

Tabel 6. Hasil uji ANOVA daya lekat

\begin{tabular}{lrrrrrr}
\hline Source & $\begin{array}{c}\text { Sum of } \\
\text { Squares }\end{array}$ & $\boldsymbol{d} \boldsymbol{f}$ & Mean Square & F-value & $\boldsymbol{p}$-value & \\
\hline Model & 147,46 & 1 & 147,46 & 1029,53 & $<0.0001$ & significant \\
$\begin{array}{l}{ }^{(1)} \text { Linear } \\
\text { Mixture }\end{array}$ & 147,46 & 1 & 147,46 & 1029,53 & $<0.0001$ & \\
Residual & 0,4297 & 3 & 0,1432 & & & \\
Cor & 147,89 & 4 & & & & \\
Total & & & & & & \\
\hline
\end{tabular}

Model tersebut memiliki nilai probabilitas model dengan $p$-value sebesar 0,0001 artinya signifikan dimana peluang yang didapatkan di luar toleransi peneliti $<0,05$. Berdasarkan nilai tersebut hanya 0,01\% kemungkinan terjadi noise. Nilai lack of fit (F-value) sebesar 1029,53 yang menunjukkan tidak signifikan. Nilai F-value yang tidak signifikan adalah syarat untuk model yang baik karena menandakan adanya kesesuaian data dengan respon. Profil kurva dari model prediksi respon daya lekat tersaji pada Gambar 3.

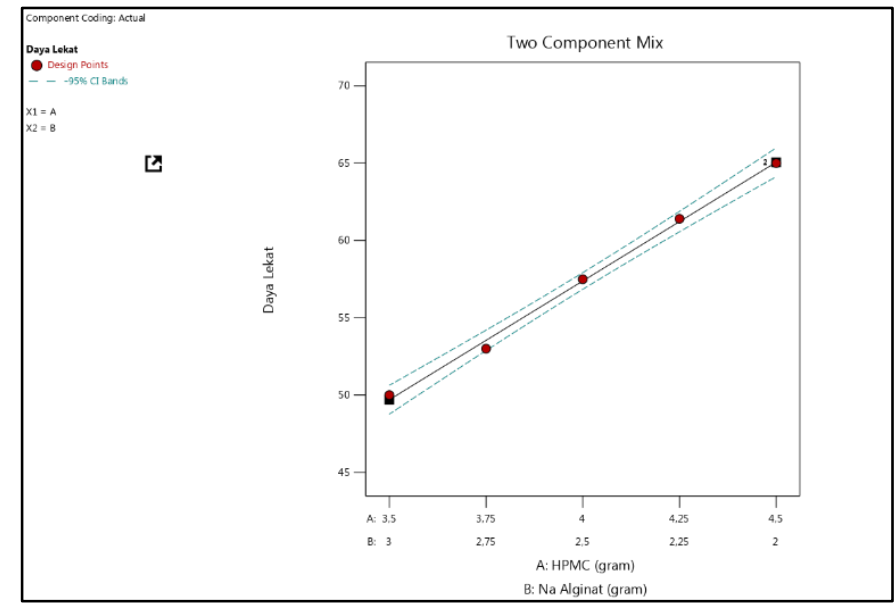

Gambar 3. Grafik hubungan kombinasi gelling agent terhadap daya lekat gel

Grafik pada Gambar 3 memperlihatkan bahwa semakin tinggi konsentrasi HPMC maka semakin tinggi daya lekat sediaan, sedangkan semakin tinggi natrium alginat akan menurunkan daya lekat. Hal ini terjadi karena penggunaan HPMC menghasilkan sediaan dengan konsistensi kental sehingga viskositasnya tinggi dan menjadi daya lekatnya lebih lama karena lebih kuat melekat. Natrium alginat akan menurunkan daya lekat karena sifatnya yang menyerap air sehingga sediaan yang dihasilkan tidak begitu kental. 
118 Putri, W. E., dkk /Jurnal Ilmiah Farmasi (Scientific Journal of Pharmacy) Special Edition 2022, $107-120$

\subsubsection{Formula optimal}

Optimasi dilakukan menggunakan pendekatan numeric dengan goal kriteria respon yang diinginkan yaitu daya sebar yang maksimum, daya lekat dan viskositas in range. Hasil optimasi yang diperoleh dari software tersaji pada Gambar 4.

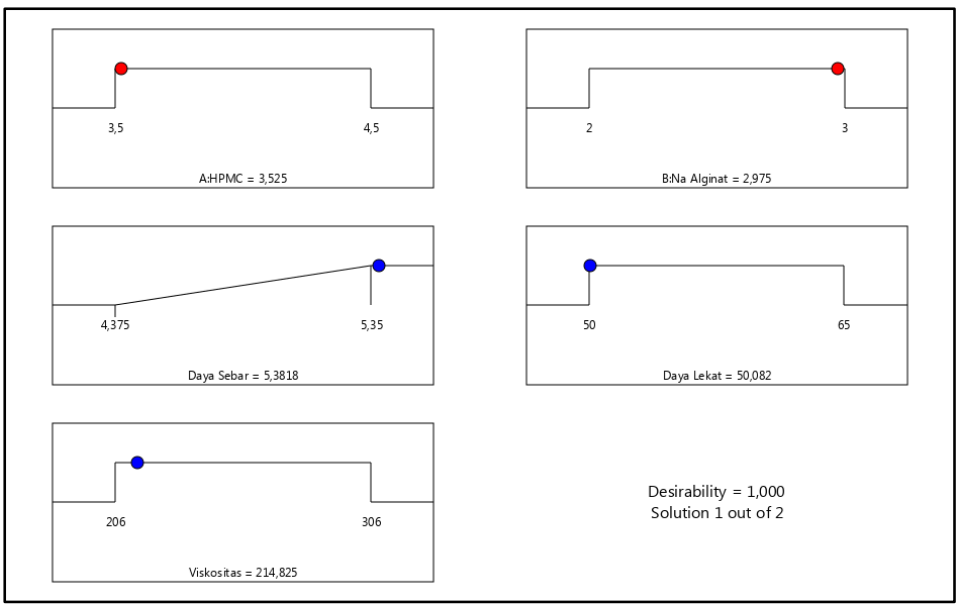

Gambar 4. Formula yang direkomendasikan software

Formula optimal yang direkomendasikan oleh software adalah formula dengan komposisi HPMC sebesar 3,53 gram dan komposisi natrium alginat sebesar 2,98 gram dengan nilai desirability 1,00. Hasil menunjukkan kemampuan program untuk menghasilkan produk yang diinginkan mendekati sempurna.

\subsection{Hasil uji formula optimal}

Tabel 7. Hasil uji formula optimal

\begin{tabular}{cclccc}
\hline \multirow{2}{*}{ HPMC (\%) } & \multirow{2}{*}{ Na alginat (\%) } & \multirow{2}{*}{ Replikasi } & \multicolumn{2}{c}{ Daya sebar (cm) } & Daya sebar prediksi \\
\cline { 3 - 4 } & & Nilai & Mean & SLD (cm) \\
\hline 3,52 & 2,97 & $\mathrm{~F}(\mathrm{~A})$ & 5,35 & 5,37 & 5,38 \\
\cline { 3 - 4 } & & $\mathrm{F}(\mathrm{B})$ & 5,38 & & \\
\cline { 3 - 4 } & & $\mathrm{F}(\mathrm{C})$ & 5,38 & & \\
\hline
\end{tabular}

Keterangan

$\mathrm{FX}_{\mathrm{X}(\mathrm{A}-\mathrm{C})}=$ Kode formula

Berdasarkan hasil pengujian daya sebar seperti tersaji pada Tabel 7 dapat disimpulkan bahwa respon percobaan sesuai dengan prediksi nilai respon daya sebar SLD. Hasil penelitian dilakukan uji-t menggunakan Microsoft Excel 2016 untuk mengetahui sejauh mana ketepatan prediksi software. Diperoleh hasil nilai t hitung sebesar -8,70031 dan $t$ tabel sebesar 2,57058 yang artinya t hitung lebih kecil dari t tabel. Hal ini menandakan bahwa software dapat memprediksi dengan baik respon berupa daya sebar sediaan gel. 
119 | Putri, W. E., dkk /Jurnal Ilmiah Farmasi (Scientific Journal of Pharmacy) Special Edition 2022, $107-120$

\section{Kesimpulan}

Kombinasi HPMC dan natrium alginat pada Formula 1 dan 2 menghasilkan sediaan yang memenuhi kriteria sifat fisik meliputi organoleptis, homogenitas, $\mathrm{pH}$, viskositas, daya sebar dan daya lekat. Formula 3, 4 dan 5 tidak memenuhi kriteria daya sebar yang baik, namun memenuhi kriteria organoleptis, homogenitas, $\mathrm{pH}$, viskositas serta daya lekat.

Formula gel ekstrak etanol buah kapulaga yang optimal diperoleh dengan proporsi HPMC : natrium alginat sebesar 3,52\% : 2,97\% dengan prediksi respon daya sebar sebesar 5,38 cm. Pengujian formula optimal menunjukkan nilai daya sebar sebesar 5,37 cm. Berdasarkan penelitian ini dapat disimpulkan bahwa simplex lattice design dapat digunakan untuk optimasi penggunaan variasi HPMC dan natrium alginat sebagai gelling agent dalam formula gel ekstrak buah kapulaga.

\section{Daftar pustaka}

Agoes, G. (2012). Sediaan Farmasi Likuida-Semisolida (1 ed.). Bandung: Penerbit ITB.

Ansel, H. C. (1989). Pengantar Bentuk Sediaan Farmasi (4 ed.). Jakarta: Universitas Indonesia Press.

Bolton, S. (1997). Pharmaceutical Process Validation (R. A. Nash \& A. H. Wachter Eds. 3 ed.): Marcel Dekker, Inc.

Draelos, Z. D., \& Thaman, L. A. (2006). Cosmetic Formulation of Skin Care Product (1 ed. Vol. 30): CRC Press.

Fulviana, M. (2013). Formulasi Sediaan Gel Antibakteri Ekstrak Etanol Herba Patikan Kebo (Euphorbia hirta L.) dan Uji AKtivitas Secara In Vitro terhadap Pseudomonas aeruginosa. (Skripsi). Universitas Muhammadiyah Surakarta Surakarta. Retrieved from http://eprints.ums.ac.id/id/eprint/24186

Lachman, L., Lieberman, H. A., Kaning, J. L., Suyatmi, S., Kaning, L., \& Suyatmi, S. (1994). Teori dan Praktek Farmasi Industri (2 ed.). Jakarta: Universitas Indonesia Press.

Naibaho, O. H., Yamlean, P. V., \& Wiyono, W. (2013). Pengaruh Basis Salep terhadap Formulasi Sediaan Salep Ekstrak Daun Kemangi (Ocimum sanctum L.) pada Kulit Punggung Kelinci yang Dibuat Infeksi Staphylococcus aureus. Pharmacon, 2(2).

Septiani, S., Wathoni, N., \& Mita, S. R. (2012). Formulasi Sediaan Masker Gel Antioksidan dari Ekstrak Etanol Biji Melinjo (Gnetun gnemon Linn.). Students e-Journal, 1(1).

Sukandar, D., Hermanto, S., Amelia, E., \& Zaenudin, M. (2016). Aktivitas Antibakteri Ekstrak Biji Kapulaga (Amomum compactum Sol. Ex Maton). Jurnal Kimia Terapan Indonesia, 17, 119-129. doi:10.14203/jkti.v17i2.28

Sumayyah, S., \& Salsabila, N. (2017). Obat Tradisional: Antara Khasiat dan Efek Sampingnya. Majalah Farmasetika, 2(5).

Suyudi, S. D. (2014). Formulasi Gel Semprot Menggunakan Kombinasi Karbopol 940 dan Hidroksipropil Metilselulosa (HPMC) sebagai Pembentuk Gel. (Skripsi). UIN Syarif Hidayatullah Jakarta, Jakarta.

Voigt, R. (1994). Buku Pelajaran Teknologi Farmasi (5 ed.). Yogyakarta: Gadjah Mada University Press.

Yulia, A., Esti, H., \& P, T. (2021). Karakteristik Sediaan dan Pelepasan Natrium Diklofenak dalam Sisten Niosom dengan Basis Gel Carbomer 940. PharmaScientia, 1(1), 2. 
120 Putri, W. E., dkk /Jurnal Ilmiah Farmasi (Scientific Journal of Pharmacy) Special Edition 2022, $107-120$

Yuniarto, P., Rahayu, E., \& Ekowati, D. (2012). Optimasi Formula Gel Buah Apel Hijau (Pyrus malus L.) sebagai Antioksidan dengan Kombinasi Basis Carbopol 940 dan Gliserin secara Simplex Lattice Design. Jurnal Farmasi Indonesia, 11(2), 130-138. 